\title{
Trophic Restoration of the Nigrostriatal Dopaminergic Pathway in Long-Term Carotid Body-Grafted Parkinsonian Rats
}

\author{
Juan J. Toledo-Aral, ${ }^{\star}$ Simón Méndez-Ferrer, ${ }^{\star}$ Ricardo Pardal, Miriam Echevarría, and José López-Barneo \\ Laboratorio de Investigaciones Biomédicas, Departamento de Fisiología and Hospital Universitario Virgen del Rocío, Universidad de Sevilla, E-41013 \\ Sevilla, Spain
}

We studied the mechanisms underlying long-term functional recovery of hemiparkinsonian rats grafted intrastriatally with carotid body (CB) cell aggregates. Amelioration of their motor syndrome is a result of the trophic actions of these grafts on the remaining ipsilateral substantia nigra neurons rather than of the release of dopamine from the CB grafts. The grafts maintain a stable morphological appearance and differentiated cell phenotype for the duration of the life of the host. Adult CB expresses high levels of glial cell line-derived neurotrophic factor (GDNF) and the multicomponent GDNF receptor complex. These properties may contribute to the trophic actions of the CB transplants on nigrostriatal neurons and to their extraordinary longevity. We show that CB glomus cells, although highly dopaminergic, are protected from dopamine-mediated oxidative damage because of the absence of the high-affinity dopamine transporter. Thus, intrastriatal CB grafts are uniquely suited for long-term delivery of trophic factors capable of promoting restoration of the nigrostriatal pathway.

Key words: nigrostriatal dopaminergic neurons; carotid body grafts; long-term recovery; glial cell line-derived neurotrophic factor; dopamine transporter; Parkinson's disease

\section{Introduction}

Because Parkinson's disease (PD) results primarily from degeneration of nigrostriatal neurons, intrastriatal transplantation of dopamine-secreting cells has been used as a therapeutic approach for this disorder (Lang and Lozano, 1998a,b; Rosenthal, 1998; Dunnett and Bjorklund, 1999). Among the various dopaminergic tissues tested in animal models of PD and in Parkinson's patients, allografts (and occasionally xenografts) of fetal mesencephalic neurons are an efficacious therapy in humans (for review and references, see Björklund et al., 1987; Sladek and Gash, 1988; Freed et al., 1992, 2001; Kordower et al., 1995; Deacon et al., 1997). These pioneer transplantation studies have, however, set the limitations of cell replacement therapies in PD. Intrastriatal grafts of mesencephalic neurons increase dopamine concentration locally but have little restorative action on the nigrostriatal pathway. Moreover, the use of human fetal cells raises numerous ethical, legal, and practical issues (e.g., scarcity of human embryonic tissue), whereas the use of xenografts is hampered by the need for sustained immunosuppression. Intracerebral adminis-

Received July 10, 2002; revised 0ct. 8, 2002; accepted 0ct. 16, 2002.

This research was supported by grants from the Fundación La Caixa, the Fundación Ramón Areces, and the Consejería de Salud of the Andalusian Government. S.M.-F. is a predoctoral fellow of the Spanish Formación de Personal Investigador program. J.L.-B. received the "Ayuda a la Investigación 2000" of the Juan March Foundation. We thank Drs. A. Nieto, M. T. Herrera, and J. Villadiego-Luque for technical help in some experiments and Dr. G. Gasic for comments on this manuscript. We also thank Dr. M.-P. Martres for kindly providing us with the PRc-CMV DAT plasmid and Dr. Inmaculada Silos-Santiago for the generous gift of the GDNF-lacZ mouse.

*J.J.T.-A. and S.M.-F. contributed equally to this work.

Correspondence should be addressed to Dr. Juan José Toledo-Aral, Laboratorio de Investigaciones Biomédicas, Edificio de Laboratorios, $2^{\text {a }}$ planta, Hospital Universitario Virgen del Rocío, Avenida Manuel Siurot s/n, E-41013 Sevilla,Spain. E-mail: juanjo@hvr.sas.junta-andalucia.es.

Copyright $\odot 2002$ Society for Neuroscience $\quad 0270-6474 / 02 / 220141-\bullet \$ 15.00 / 0$ tration of trophic factors for dopaminergic neurons (Gash et al., 1996; Choi-Lundberg et al., 1997; Rosenthal, 1999; Kordower et al., 2000; Akerud et al., 2001) and autotransplantation of dopaminergic carotid body (CB) cell aggregates (Espejo et al., 1998; Luquin et al., 1999; Mínguez et al., 2001) are two approaches that have been developed recently in animal models to complement fetal cell grafts.

The CBs contain neural crest-derived, highly dopaminergic glomus cells, which function as arterial oxygen sensors releasing dopamine in response to hypoxia (for review, see López-Barneo et al., 2001). Unlike many other organs, CBs were presumed to be particularly well suited for intracerebral transplantation because hypoxia, an environmental condition that is likely to be present inside the grafts, makes the CB grow (McGregor et al., 1984). Moreover, CBs offer potential clinical advantages because their unilateral surgical resection has no significant side effects (Honda, 1992) and therefore can be used for autografts. Intrastriatal transplants of CB cell aggregates are able to effect notable histological and functional recovery of parkinsonian rats (Espejo et al., 1998) and 1-methyl-4-phenyl-1,2,3,6-tetrahydropyridine (MPTP)-treated monkeys (Luquin et al., 1999). In addition, a pilot study on $\mathrm{PD}$ patients subjected to unilateral resection of the $\mathrm{CB}$ and bilateral transplantation of the tissue into the putamen has proven the feasibility and safety of this therapy in humans (Mínguez et al., 2001).

Although results obtained so far with CB grafts are promising, the mechanisms of action and long-term viability of the implants remain unknown. Here, we show that amelioration of parkinsonian rats with $\mathrm{CB}$ transplants is a result of their trophic effect on the ipsilateral nigrostriatal neurons rather than the local release of dopamine. CB grafts have an extraordinary durability and can 


\section{A \\ GRAFTED ANIMALS Group I \\ (good functional recovery)}
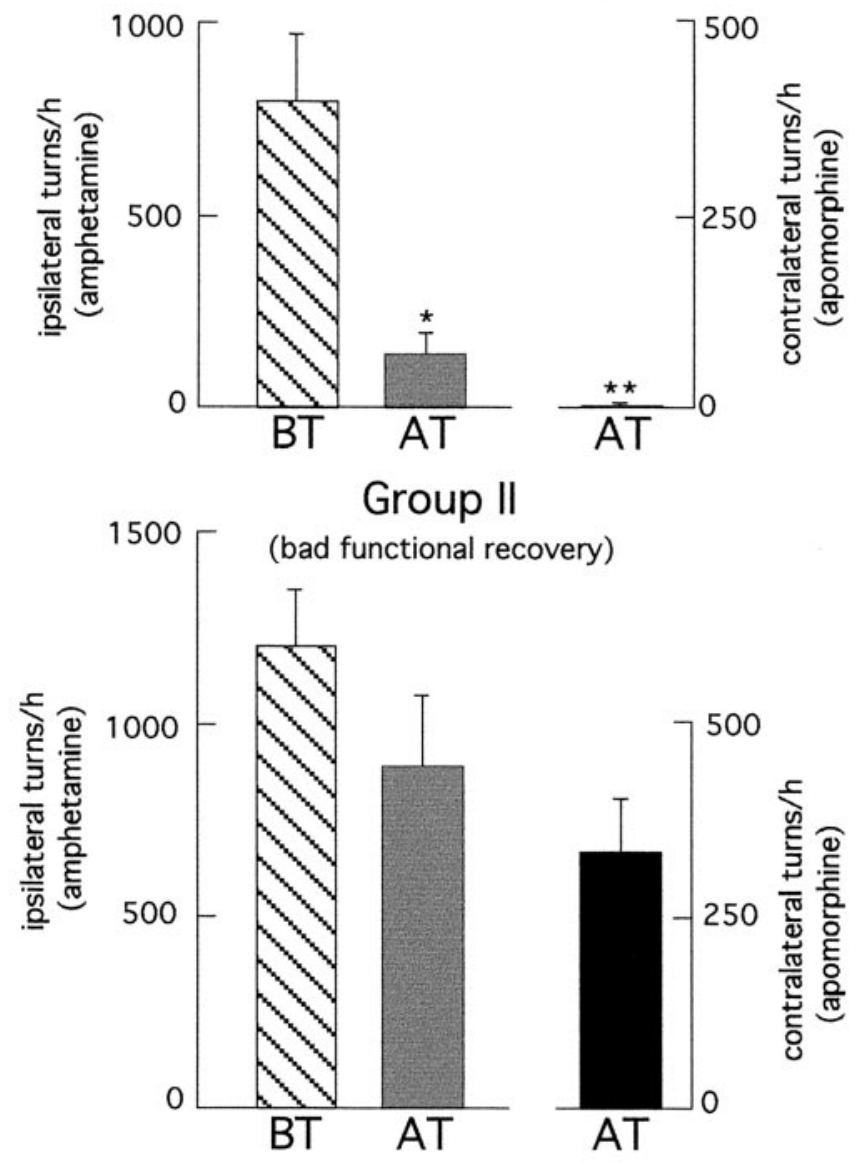

B

\section{SHAM OPERATED ANIMALS}

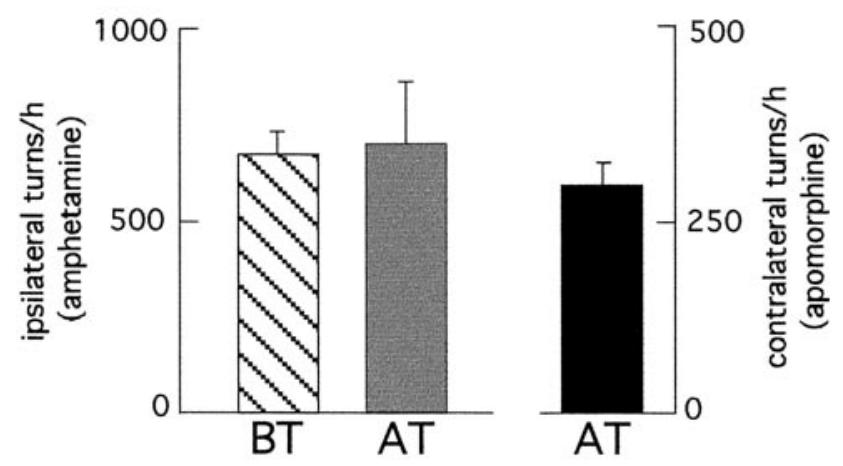

Figure 1. Long-term functional recovery of (B-grafted hemiparkinsonian rats. $A$, Evolution of the rotational behavior in (B-grafted animals measured before the transplantation ( $B T$ ) or at the end of the period they were allowed to survive (between 5 and 15 months) (AT). Animals' behavior was evaluated by the amphetamine (left ordinate) and apomorphine (right ordinate) tests. Animals were classified in groups I and II depending on the behavioral and histological characteristics (see Results). Apomorphine tests were done only on animals that had some functional recovery in the amphetamine test to detect upregulation of dopamine receptors. Behavioral status is as follows (mean \pm SEM in turns per hour): group I, amphetamine test, $\mathrm{BT}=787 \pm 171(n=6)$ and $\mathrm{AT}=138 \pm 53(n=6) ;$ apomorphine test, $\mathrm{AT}=3 \pm 5(n=$ 5); group Il, amphetamine test, $\mathrm{BT}=1206 \pm 145(n=6)$ and $\mathrm{AT}=872 \pm 179(n=6)$; apomorphine test, $A T=328 \pm 133(n=3)$. $B$, Same analysis as in $A$ performed in the group of last almost the entire life of the animal. We demonstrate that the adult CB expresses high levels of glial cell line-derived neurotrophic factor (GDNF), which may contribute to the longevity of the grafts and to their trophic effect on nigrostriatal neurons. We also show that CB glomus cells lack expression of the dopamine transporter (DAT) and are resistant to dopamine-mediated oxidative damage.

\section{Materials and Methods}

Unilateral 6-hydroxydopamine-induced substantia nigra lesion, CB grafting, and chronic MPTP-treated mice. Female Wistar rats (250-300 gm) were housed at regulated temperature $\left(22 \pm 1^{\circ} \mathrm{C}\right)$ in a $12 \mathrm{hr}$ light/dark cycle, with access ad libitum to food and water. General procedures to produce unilateral 6-hydroxydopamine (6-OHDA) (Sigma, St. Louis, $\mathrm{MO}$ ) substantia nigra (SN) lesions and transplantation surgery in rats were as described previously (Espejo et al., 1998; Toledo-Aral et al., 2002). Parkinsonian animals received transplants 10-15 d after SN lesion. For transplantation, carotid bodies were trimmed into pieces approximately one-third the size of the whole organ. A carotid body piece was placed on $1 \mu \mathrm{l}$ of Tyrode's solution and injected into the striatum after stereotaxic coordinates in reference to bregma (in $\mathrm{mm}$ ): anteroposterior (AP), +0.2; lateral (L), +3; ventral (V), -6. Sham-operated animals received only $1 \mu \mathrm{l}$ of Tyrode's solution. Mice of the Swiss and C57BL/6 strains received subcutaneous MPTP injections either daily $(5-30 \mathrm{mg} / \mathrm{kg}$ ) or weekly $(20-40 \mathrm{mg} / \mathrm{kg}$ ) during 1 week to 3 months. All experiments were performed according to the animal care guidelines of the European Communities Council (86/609/EEC).

Histological analyses. Rat and mouse brains and carotid bifurcations were removed and fixed overnight at $4^{\circ} \mathrm{C}$ with $4 \%$ paraformaldehyde in PBS. Slices 30-100 $\mu \mathrm{m}$ thick were cut with a Vibratome (Vibratome, St. Louis, MO). Histological analysis was as previously described (Nieto et al., 1996; Pardal et al., 2000; Echevarría et al., 2001). For immunohistochemical studies, we used a polyclonal anti-tyrosine hydroxylase (TH) antibody [1:1000; for rat, Chemicon (Temecula, CA); for mice, Pel-Freez (Rogers, AR)] and a secondary anti-rabbit antibody (1:200; Pierce, Rockport, IL). The level of reinnervation by TH-positive fibers in the CBgrafted striatum was estimated by measuring the percentage of reinnervated area compared with the intact contralateral side. To make this calculation, all of the coronal sections of the striatum stained with the TH antibody (10-14 sections per animal) were photographed and digitized. The areas of TH immunoreactivity in both the normal and the grafted striatum of each slice were calculated by computer using the appropriate tools of Canvas 6.0 (Deneba Systems, Miami, FL).

In situ hybridization against $\mathrm{TH}$ and DAT was done using digoxigenin UTP-labeled antisense riboprobes synthesized from two plasmids (pCR2.1-TH and pRc/CMV-DAT) (Martres et al., 1998) containing partial cDNA sequences for TH and DAT, respectively. After hybridization, the sections were incubated with alkaline phosphataseconjugated anti-digoxigenin antibody (1:1000; Roche Diagnostics, Mannheim, Germany).

Under chloral hydrate anesthesia (350 mg/kg, i.p.), some rats received Fluorogold (FG) (Fluorochrome, Denver, CO) injections $24 \mathrm{hr}$ before the brain was removed. Two stereotactic deposits of $0.1 \mu \mathrm{l}$ of a $4 \%$ Fluorogold solution in saline were done $(\mathrm{AP}+1.3, \mathrm{~L}+2.5, \mathrm{~V}-5.5$; and AP $-0.9, \mathrm{~L}+3.5, \mathrm{~V}-5.5$ ). Injections were made with a Stoelting (Wood Dale, IL) infusion pump at a rate of $0.05 \mu \mathrm{l} / \mathrm{min}$. The cannula was left in place for $10 \mathrm{~min}$ after each injection before being slowly retracted. Heterozygous GDNF/lacZ mice 4 months old were used for the 5-bromo-4chloro-3-indolyl- $\beta$-D-galactopyranoside (X-gal) staining (Sánchez et al.,

$\leftarrow$

sham-operated animals that rotated $<900$ turns per hour. Behavioral status is as follows (mean \pm SEM in turns per hour): amphetamine test, $\mathrm{BT}=671 \pm 54(n=8)$ and $\mathrm{AT}=702 \pm$ $159(n=8)$; apomorphine test, $\mathrm{AT}=298 \pm 27(n=3) .{ }^{*} p<0.02$, statistically significant with respect to $B$ in the same group ( $t$ test); ${ }^{* *} p<0.02$, statistically significant with respect to the same test in group $I I$ and in $B$ ( $t$ test). 
1996). For colocalization studies, TH immunohistochemistry was performed after the X-gal staining.

Behavior and pharmacological assessment. Hemiparkinsonian rats were randomly allocated into two groups: grafted $(n=16)$ and sham operated $(n=16)$. Within the first group, four animals were discarded later in our analysis because the graft was either dead or located outside the striatum. Amphetamine-induced (5 mg/kg, i.p.; Sigma) rotation was evaluated $8 \mathrm{~d}$ after unilateral nigra lesion and $10 \mathrm{~d}$ after transplantation. Apomorphine $(0.5 \mathrm{mg} / \mathrm{kg}$, s.c.; Sigma) tests were done only on animals that had some functional recovery in the amphetamine test to detect upregulation of dopamine receptors. Rats were tested monthly for rotational behavior induced by amphetamine and when necessary by apomorphine (Schwarting and Huston, 1996). Amphetamine and apomorphine tests were alternated every 2 weeks. Rotations were measured in an automated rotometer (Letica, Barcelona, Spain) after the injection. The parameter used for analysis was the number of rotations during the hour of maximum effect of the drug. Values are given as mean \pm SEM. The statistical significance of differences among parameters was considered at a value of $p \leq 0.05$ (Student's $t$ test).

Molecular biology. To perform reverse transcription (RT)-PCR, poly $\left(\mathrm{A}^{+}\right)$RNA was extracted from either slices or intact carotid bodies using the Dynabeads mRNA Direct micro kit (Dynal, Oslo, Norway) as indicated by the manufacturer. Between 10 and 20 whole carotid bodies or the equivalent amount of tissue from the superior cervical ganglion (SCG) or the SN were used (Pardal et al., 2000; Echevarría et al., 2001). The reverse transcription reaction was performed immediately after the mRNA isolation using SuperScript II RNase $\mathrm{H}^{-}$reverse transcriptase (Invitrogen, Carlsbad, CA). Standard PCR was done with 1-5 $\mu$ l of firststrand cDNA. The primers used to amplify the different genes were as follows: for TH, sense, GGACATTGGACTTGCATCTCTGGG and antisense, TGAGAAGCAGTGTTGGGAGGATGG; for GDNF, sense, TGAAGTTATGGGATGTCGTGGCTG, antisense A, AAGTGTATTGCAGTTAAGACGC (band of $372 \mathrm{bp}$ ), and antisense B, ATCCACACCGTTTAGCGGAATGC (band of $627 \mathrm{bp}$ ); for GDNF family receptor $\alpha 1$ (GFR $\alpha 1$ ), sense, ATGTTCCTAGCCACTCTGTACTTCG and antisense, GGTTGCAGACCTCGTTGGACATGC; for c-ret, sense, GCGCCCCGAGTGTGAGGAATGTGG, and antisense, GCTGATGCAATGGGCGGCTTGTGC (as by Moreau et al., 1998); and for DAT, sense, TATAGAGACGCAATCATCACCAC and antisense, AGCAGGAAAGTAGCCAGGACAAT. In every case, the band of the expected size was gel purified and cloned into the pCR2.1 vector (Invitrogen, Carlsbad, CA), and its identity was finally confirmed by sequencing using the dideoxynucleotide chain termination method with the Sequenase 2.0 kit (United States Biochemicals, Cleveland, $\mathrm{OH}$ ). For TH, the partial sequence of 599 bp amplified by PCR and cloned into the pCR2.1 vector was the one used as a template to produce the antisense riboprobe after linearization of the pCR2.1-TH.

\section{Results \\ Functional recovery of CB-grafted animals depends on nigrostriatal reinnervation}

To perform this study, we prepared hemiparkinsonian rats with extensive lesions of the left SN (991 \pm 64 ipsilateral turns per hour in amphetamine test; $n=32$ ). Animals were left to recover between 5 and 15 months after either CB transplantation $(n=$ $16)$ or sham surgery $(n=16)$ to study the long-term evolution of the grafts. We found healthy grafts in $>80 \%$ of the animals that received transplants, even if they were left to recover for $>7$ ( $n=$ $4)$ or $11(n=2)$ months. The percentage of graft survival is similar to that observed in animals killed within 3 months after the surgery (our unpublished data), suggesting that the grafts of $\mathrm{CB}$ tissue that overcome the transplantation trauma can maintain a stable phenotype for almost the entire life of the animal.

Functional recovery of the whole group of CB-transplanted animals, estimated with the amphetamine test, was statistically significant (in turns per hour, $1000 \pm 124$ before transplantation and $505 \pm 142$ after transplantation; $n=12 ; p<0.02$ ). In contrast, the surgery had no significant behavioral effect on sham- operated animals (in turns per hour, $999 \pm 76$ before transplantation and $737 \pm 119$ after transplantation; $n=16 ; p=0.2$ ). On the basis of the behavioral (apomorphine test) and histological characteristics of the CB-grafted animals (see below), we classified them in two clearly distinct groups. Animals in group I had an average $\sim 85 \%$ stable recovery in the amphetamine test and did not rotate after administration of apomorphine $(n=6)$ (Fig. $1 A$ ), indicating a truly good functional recovery after transplantation with lack of dopamine supersensitivity. The analysis of the time course of recovery indicated significant functional improvement at 1 month (55\%), which increased at 3 months $(72 \%)$ and was almost complete $(81 \%)$ at 5 months. Later, functional recovery remained stable or with slight additional improvement. Animals in group II manifested an asymmetrical sensitivity to apo-
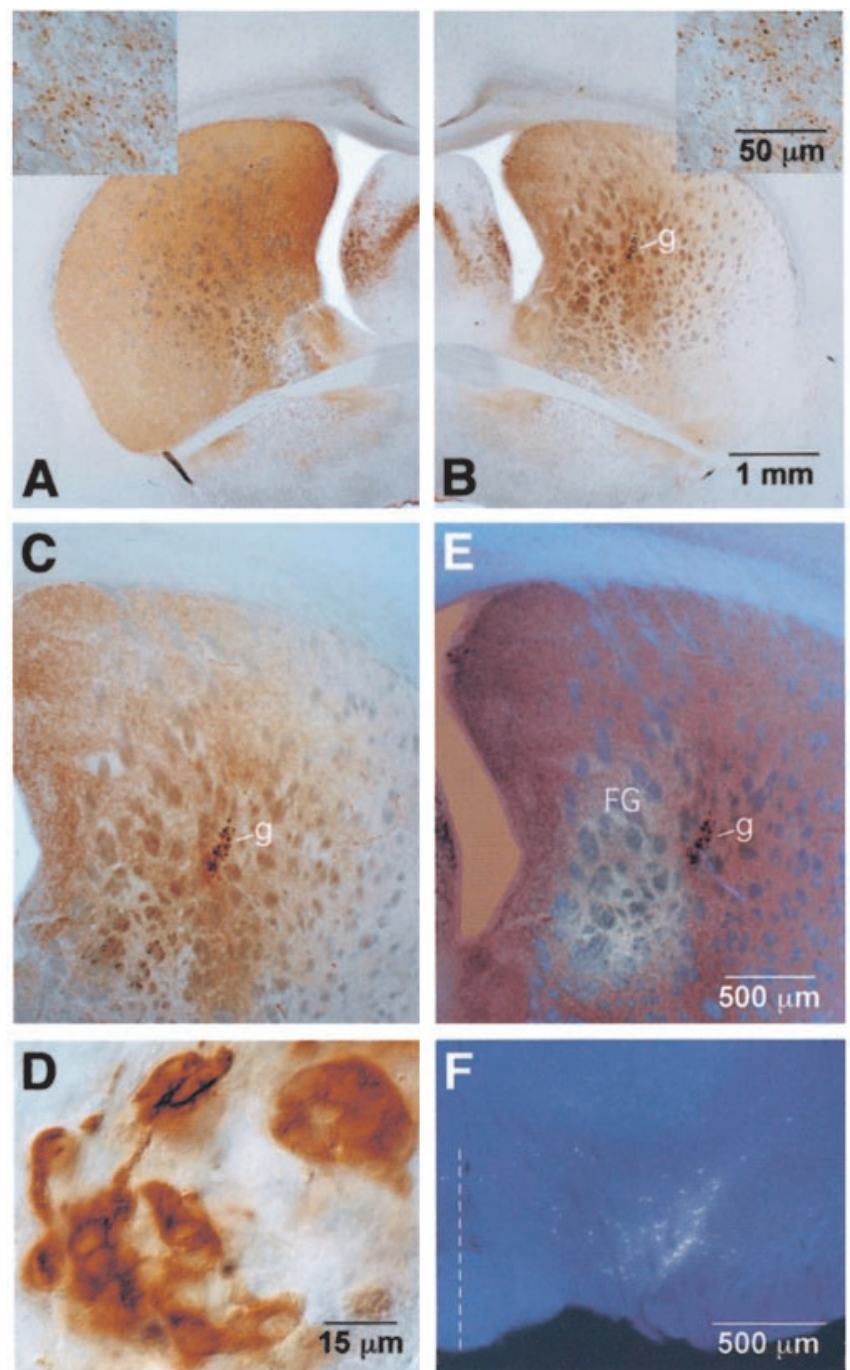

Figure 2. Long-term striatal reinnervation and survival of substantia nigra neurons in carotid body-grafted rats. $A-D$, Striatal dopaminergic reinnervation in a representative animal of group I killed 5.5 months after carotid body transplantation (AT). BT, Before transplantation. Normal $(A)$ and reinnervated $(B)$ striata are shown for comparison. Insets at high magnification show the appearance of TH-positive striatal fibers. The region with the carotid body graft $(g)$ is shown in $C$ and $D$ at higher magnifications. Note the numerous typical glomus cells in the graft arranged in glomeruli. E, Localization of FG injection in the striatum near the graft. $F$, Retrograde labeling of numerous cells in the ipsilateral substantia nigra. Midline is indicated by the dotted line. $A-E$, Transmitted light and immunostaining with antibody against TH. E, F, UV illumination. Behavioral parameters of this animal (turns per hour) were as follows: amphetamine test, $B T=1512$ and $A T=111$; apomorphine test, $A T=-9$. Striatal reinnervation, $70.7 \%$. 
morphine and had a poor recovery in the amphetamine test $(n=6)$ (Fig. $1 A)$, indicating a striatal denervation with a compensatory upregulation of dopamine receptors. Differences in the number of turns per hour before transplantation between animals distributed later on in groups I $(787 \pm 171)$ and II $(1206 \pm 145)$ were not statistically significant. We followed the parallel evolution of a group of sham-operated hemiparkinsonian animals with a mean value of turns $(671 \pm 54$ turns per hour) comparable with that of group I animals. On average, these shamoperated animals did not recover in the amphetamine test, and those with some apparent amelioration manifested a clear motor asymmetry in response to apomorphine (Fig. $1 B$ ). Thus, these data indicated that long-term functional recovery of hemiparkinsonian rats required the presence of $\mathrm{CB}$ transplants in the striatum.

Differences in the level of functional recovery described above were correlated with distinct degrees of histological restoration (striatal reinnervation, $69.5 \pm$ $3.7 \%, n=6$ for group I; $4.9 \pm 2.2 \%, n=6$ for group 2). Figure $2 A-D$ illustrates the appearance of the striata of a rat representative of group I after TH immunostaining. Comparison of the unlesioned $(A)$ and transplanted $(B)$ sides shows an important reinnervation that affects primarily the central and medial regions of the striatum. TH-positive fibers were particularly dense in the region surrounding the graft, which appeared as a dense mass of intensely stained TH-positive glomus cells (Fig. 2C) organized in clusters similar to the glomeruli of the carotid body (Fig. 2D). The origin of the dopaminergic fibers was studied by injection of FG, a fluorescent retrograde tracer, in the striatum near the center of the reinnervated area (Fig. 2 E). Fluorescent cells were observed in the ipsilateral $\mathrm{SN}$, primarily in the medial region of the pars compacta, and in the lateral part of the ventral tegmental area (VTA) (Fig. 2 F). With the exception of a few cells encountered in the contralateral SN, TH-positive cells filled with FG were not appreciable in the CB graft or anywhere else in the brain. This distribution of FG-positive cells was repeated in the four group I animals studied. Intrastriatal FG injection in four sham-operated animals showed almost complete absence of fluorescent cells in the SN (data not shown). These results show that functional recovery of CB-grafted animals is correlated with striatal reinnervation by fibers originating in ipsilateral nigrostriatal neurons.

The histological appearance of the nigrostriatal system in animals with poor functional recovery (group II) is illustrated in Figure 3. The striatum ipsilateral to the lesion was almost completely denervated (Fig. 3, compare $A, B$ ) despite the presence of a large graft, well placed in the center of the striatum (Fig. $3 B, C$ ) with numerous intensely stained glomus cells (Fig. $3 D, E$ ). Striatal denervation was paralleled by an extensive destruction of ipsilateral mesencephalic dopaminergic neurons, with an almost absolute absence of TH-positive neurons in the $\mathrm{SN}$ and a marked reduction of staining in the adjacent VTA (Fig. 3F-I). These observations indicate that CB grafts by themselves are not sufficient to reverse parkinsonian symptoms in animals with complete nigra lesions. Together, the behavioral and histological analyses indicate that the beneficial effect of CB grafts on parkinsonian animals is predominantly a result of their trophic effects on the remaining SN neurons, which are induced to innervate the striatum.

\section{GDNF is highly expressed in adult CB cells}

We studied whether CB cells are the source of the potent dopaminotrophic factor GDNF and other members of the same family (Rosenthal, 1999) that are retrogradely transported to stimulate SN neurons. Using two different sets of primers derived from rat GDNF sequences, we amplified, by RT-PCR, cDNA fragments (of 372 and $627 \mathrm{bp}$ ) from carotid bodies and by sequencing confirmed them to be derived from rat GDNF (Lin et al., 1993). The oligonucleotides flanking the $627 \mathrm{bp}$ fragment were used repeatedly to amplify GDNF in all of the different CB preparations tested $(n=9)$ (Fig. $4 A$ ). Several parallel attempts $(n=5)$ to detect GDNF from the neighboring large SCG have failed (Fig. $4 A$ ). The other GDNF-related factors studied (neurturin, artemin, and persephin) were not amplified by RT-PCR of CB tissue. However, the CB $(n=4)$ and the SCG $(n=3)$ expressed consistently the multicomponent receptor complex for GDNF (GFR $\alpha 1$ and c-ret) (Rosenthal, 1999).

GDNF is expressed in limited amounts during specific developmental stages by target tissues, and its presence in embryonic rodent CB has been reported previously (Nosrat et al., 1996; 
A
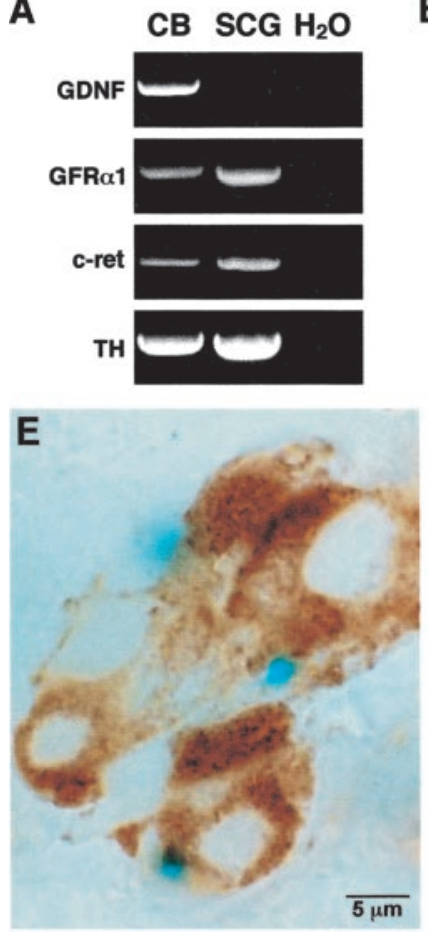
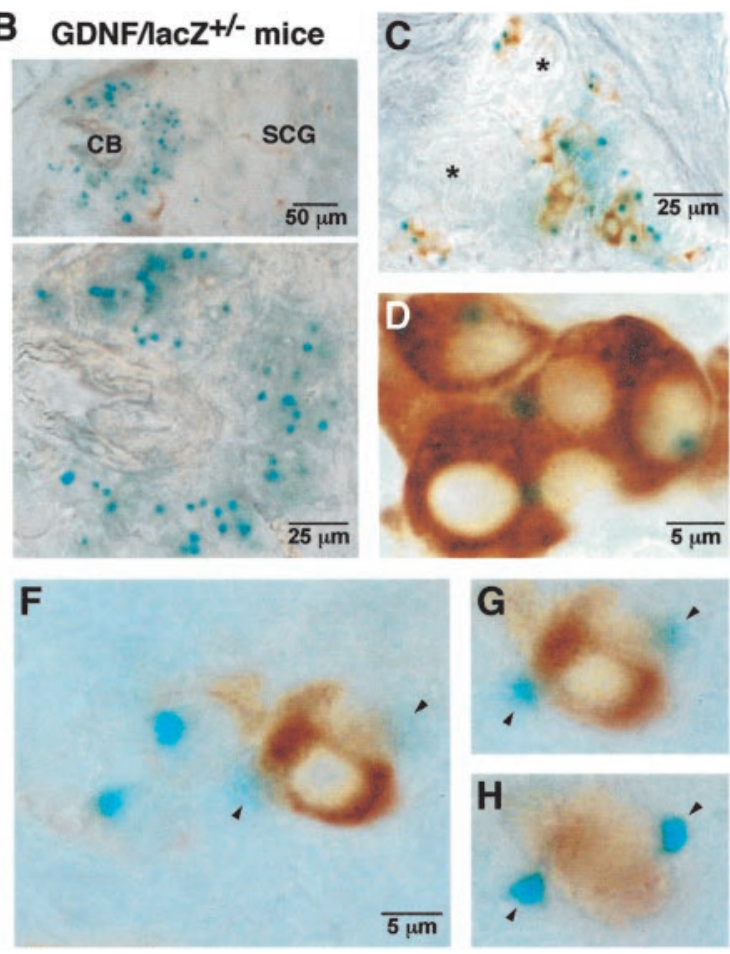

Figure 4. Identification and localization of GDNF and the GDNF multicomponent receptor complex in the carotid body. $A$, RT-PCR showing the existence of GDNF and the high-affinity GDNF receptor complex (GFR $\alpha 1$ and c-ret) in the CB. Note the parallel experiment illustrating the absence of GDNF message in the SCG. TH is also amplified to test for mRNA stability. $B, X$-gal staining (blue) of histological sections at the level of the carotid artery bifurcation from heterozygous GDNF/lacZ knock-out mice at two magnifications illustrating the dense appearance of GDNF-positive cells in the CB and the complete absence of GDNF expression in the SCG. C, Colocalization of GDNF (blue)- and TH (brown)-positive cells in the same glomeruli. Note that TH immunostaining is absent from glomeruli without GDNF-positive cells (asterisks). D, Example at higher magnification of colocalization of TH and GDNF expression. E-H, Localization of GDNF-positive cells in close apposition with TH-positive cells. $F-H$, The focus was changed in steps of $4 \mu \mathrm{m}$ to illustrate how some GDNF-positive cells (indicated by arrowheads) are arranged juxtaposed on a glomus cell.

Erickson et al., 2001). The functional role of GDNF in the adult, however, is less well studied, because its normal low level of expression, a characteristic of trophic factors, hampers its unequivocal identification by standard histological and/or immunological techniques (in situ hybridization, immunostaining, or ELISA). To study precisely the cell localization and the pattern of GDNF expression in CB of adult animals, we used heterozygous knock-out GDNF/lacZ mice, in which the cells expressing GDNF can be labeled with the characteristic blue X-gal staining (Sánchez et al., 1996). These experiments revealed that GDNF is highly expressed in the adult CB but is totally absent in the SCG and other neighboring tissues (Fig. 4B). Simultaneous X-gal and TH immunostaining showed that GDNF-producing cells are colocalized with clusters of TH-positive glomus cells (Fig. 4C,D). The deposits of X-gal appear to be preferentially located in the periphery of TH-positive cells (Fig. 4E,F) and occasionally surrounding glomus cells (Fig. $4 \mathrm{~F}-\mathrm{H}$ ). These data demonstrate that GDNF is highly and selectively expressed in CBs of adult rodents. The pattern of CB GNDF expression is consistent with its presence in glial-like subtentacular cells located in close apposition with glomus cells.

\section{Differential expression of DAT and susceptibility to neurotoxins of $\mathrm{SN}$ neurons and $\mathrm{CB}$ glomus cells}

The long-term functional recovery of transplanted rats was correlated with the survival of the $\mathrm{CB}$ tissue. Therefore, we studied whether, in addition to the local effects of trophic factors, such as

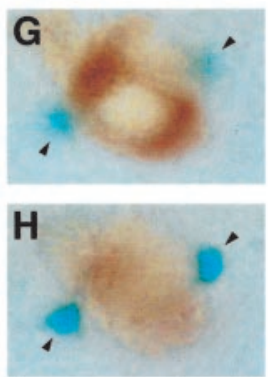

GDNF, the survival of CB grafts could also be facilitated by special features of dopamine metabolism in glomus cells that protect them from oxidative stress.

The high-affinity presynaptic dopamine reuptake system (DAT) plays a critical role in the susceptibility of SN neurons to degeneration (for review, see Jenner, 1998; Offen et al., 1999). Reuptake of dopamine results in the production of reactive oxygen species, which can induce neuronal death (Spina and Cohen 1989; Jenner, 1998; Offen et al., 1999). In addition, DAT is used for presynaptic transport of some molecules [e.g., $\mathrm{MPP}^{+}$(methyl phenylpyridinium)] with toxic effects (Burns et al., 1983; Gainetdinov et al., 1997). Although glomus cells contain and release large amounts of dopamine (Pardal et al., 2000; López-Barneo et al., 2001), we hypothesized that they should have reduced DAT activity on the basis of our previous observations on parkinsonian monkeys, which had relatively well preserved carotid bodies despite their exposure to large doses of systemically administered MPTP (Luquin et al., 1999). Differential expression of DAT on SN and CB was initially studied by in situ hybridization of mesencephalic and CB slices. Figure $5 A$ illustrates that, although DAT was abundantly expressed in SN neurons, it was not detected in the CB. Consecutive slices incubated with a $\mathrm{TH}$ probe show the high levels of expression of the enzyme in both $\mathrm{SN}$ and $\mathrm{CB}$, demonstrating the stability of the mRNA in the tissue. This experiment was repeated in SN and CB preparations from 12 different animals with identical results, suggesting that DAT is not present in $\mathrm{CB}$ cells. Additional support for this observation was obtained by high-sensitivity RTPCR analysis performed on carotid body and mesencephalic slices, showing the complete absence of the DAT message in $\mathrm{CB}$ cells ( $n=3$ experiments) (Fig. $5 B)$. To determine whether the absence of DAT expression has a functional consequence, we investigated whether glomus cells are protected from MPTP damage. We compared the effects of the neurotoxin on THpositive mesencephalic and CB cells in two different MPTPsensitive mouse strains. Whereas chronic systemic administration of MPTP resulted consistently in a marked destruction of substantia nigra and, to a lesser extent, VTA neurons, the $\mathrm{CB}$ glomus cells remained intact in all cases $(n=7)$ (Fig. $5 C$ ). These data show that $\mathrm{CB}$ cells, although highly dopaminergic, are protected from toxicity associated with the dopamine uptake system.

\section{Discussion}

In this article, we show that the beneficial effects of intrastriatal CB transplants in hemiparkinsonian rats are predominantly a result of their trophic action on intrinsic nigrostriatal neurons rather than their delivery of dopamine. Functional recovery, which was maintained for the entire life of the $\mathrm{CB}$-grafted rats, is paralleled by the long-term survival of these $\mathrm{CB}$ grafts. We demonstrated that GDNF is highly expressed in the adult CB. In con- 
A
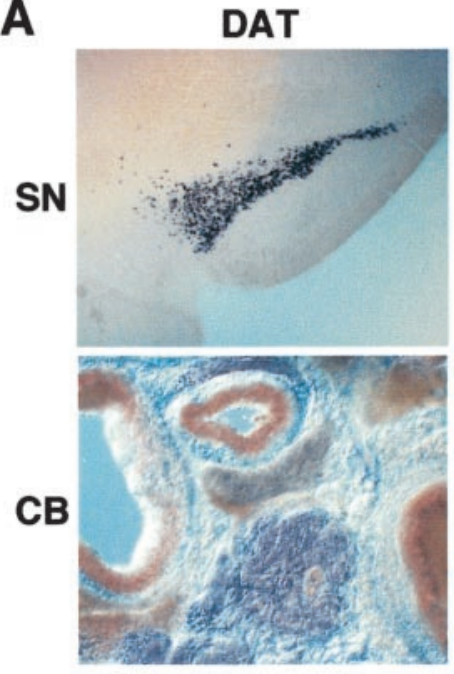

B

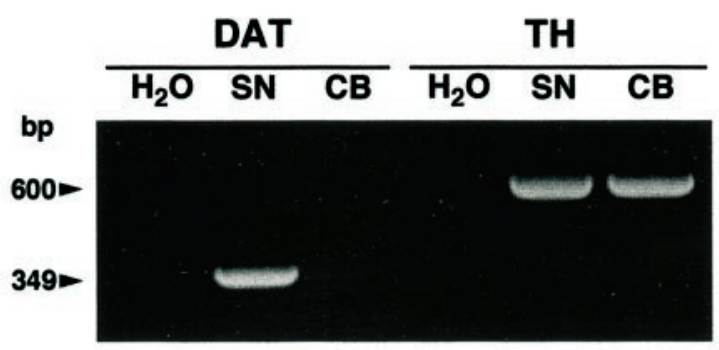

C CONTROL
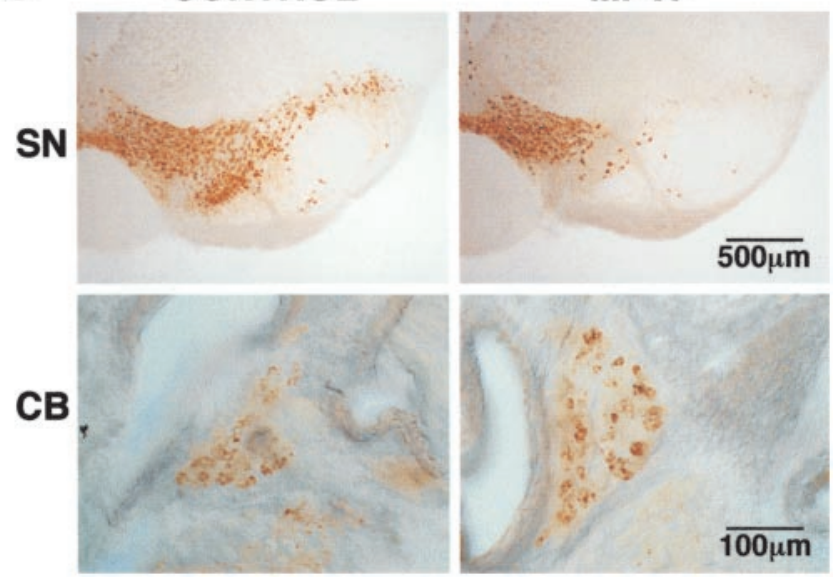

Figure 5. Differential expression of dopamine transporter in substantia nigra and carotid body cells. $A$, In situ hybridization in consecutive mesencephalic (SN) and CB slices with probes against DAT and TH mRNAs. DAT message was undetectable in CB slices. B, RT-PCR showing the lack of expression of DAT in the carotid body and comparison with SN. TH mRNA was amplified in parallel to demonstrate mRNA stability. C, TH immunohistochemistry of mesencephalic and carotid body slices from control and MPTP-treated ( $30 \mathrm{mg} / \mathrm{kg}$ daily for $55 \mathrm{~d}$ ) C57BL/6 mice. Note that systemic administration of MPTP produced a marked destruction of dopaminergic SN neurons but left intact $C B$ glomus cells.

trast, DAT, abundantly expressed in dopaminergic mesencephalic neurons, is absent from CB glomus cells, thus making them resistant to dopamine reuptake-derived toxicity. These properties of the glomus cells may contribute to the remarkable longevity of the $\mathrm{CB}$ grafts and to their trophic actions on nigrostriatal neurons.

For these experiments, we used hemiparkinsonian animals with more extensive SN lesions (average number of ampheta- mine-induced turns, $~ 990$ turns per hour) and studied them for a longer time period (up to 15 months) than in our previous work (Espejo et al., 1998; Toledo-Aral et al., 2002). One-half of the CB-transplanted animals achieved an almost complete and stable recovery of their motor asymmetries. Postmortem histological analysis of these animals demonstrated that they had intrastriatal $\mathrm{CB}$ grafts with numerous $\mathrm{TH}$-positive cells and a marked striatal dopaminergic reinnervation. In the remaining $50 \%$ of the animals with transplants, functional recovery was very poor. Although this last group of animals had well placed, large CB grafts with abundant metabolically active glomus cells, they had almost complete striatal denervation in parallel with extensive dopaminergic neuronal loss in the ipsilateral SN and adjacent VTA. These observations suggest that, to obtain a good functional recovery, CB-transplanted animals must retain a small percentage of dopaminergic SN neurons after the lesion such that the grafted $\mathrm{CB}$ cells are able to induce the remaining $\mathrm{SN}$ neurons to reinnervate the striatum. Intrinsic reinnervation has been postulated to occur after adrenal grafts (Bohn et al., 1987; Hansen et al., 1995; Gainetdinov et al., 1997) or in GDNF-injected rats (Rosenblad et al., 1998). The present study demonstrates directly that the striatal reinnervation induced by $\mathrm{CB}$ grafts is produced by fibers that originate almost exclusively in the ipsilateral $\mathrm{SN}$ and adjacent VTA. The lack of long-term recovery of any of our sham-operated animals indicates that striatal reinnervation does not result from a nonspecific reaction to brain damage or gliosis (but see Song and Haber, 2000).

The restorative activity of the CB grafts on nigrostriatal neurons could be attributable to the graft-mediated delivery of GDNF, which we showed to be highly expressed in adult CB tissue, and possibly other trophic factors. At picomolar concentrations, GDNF is capable of promoting survival and differentiation of mesencephalic dopaminergic neurons in vivo and in vitro (Lin et al., 1993; Tomac et al., 1995a; Gash et al., 1996). Moreover, GDNF delivered intrastriatally is taken up and transported retrogradely to the soma of SN neurons (Tomac et al., 1995b). Interestingly, neurotrophin-3, another well known trophic factor (Fariñas et al., 1994), is also expressed in the CB (I. Fariñas, personal communication). Thus, $\mathrm{CB}$ grafts could offer stable and regulated pumps ideal for the safe delivery of the proper mixture of growth factors capable of promoting nigrostriatal sprout and reinnervation. We did not see obvious changes in the morphology of SN neurons in the side ipsilateral to the CB grafts compared with neurons in the contralateral intact side. However, elucidation of the biochemical and morphological modifications induced by the trophic action of CB grafts on SN neurons requires additional studies in a feasible and reproducible rodent model of chronic and diffuse bilateral parkinsonism, which needs to be developed.

A remarkable observation of our study is the extraordinary longevity of $\mathrm{CB}$ grafts, which appear to be active for almost the entire life of the animal. Glomus cells in the graft maintain a stable phenotype and the typical organization in glomeruli characteristic of the native $\mathrm{CB}$. These properties may be attributable to the fact that we implanted CB cell aggregates rather than dispersed cells, suggesting that, after transplantation, the $\mathrm{CB}$ tissue has specific molecular and topological features that facilitate its adaptation to the environment in the brain parenchyma. We demonstrated that adult CB tissue expresses the GDNF multicomponent receptor complex (GFR $\alpha 1$ and c-ret) (Rosenthal, 1999). Therefore, it is plausible that GDNF released from subtentacular cells has a trophic activity on glomus cells. In addition to the bases for the paracrine effects of GDNF, we show that $\mathrm{CB}$ 
glomus cells, although highly dopaminergic, do not express DAT and are therefore not subjected to the oxidative stress inherent to dopamine metabolism, which is an important factor in the pathophysiology of PD (Spina and Cohen, 1989; Jenner, 1998; Offen et al., 1999; Conway et al., 2001). Systemic administration of MPTP in mice destroys most SN neurons but does not alter CB cells. These observations explain why glomus cells are less affected by MPTP than adrenal medulla or superior cervical ganglion cells (Ambrosio et al., 1990) and the relative preservation of carotid bodies in chronic MPTP monkeys (Luquin et al., 1999). The longevity of glomus cells could also be facilitated by their physiological role as oxygen sensors, because it is known that hypoxia, a deleterious condition in most tissues, makes the carotid body grow (McGregor et al., 1984; López-Barneo et al., 2001). Interestingly, hypoxia has also been shown to stimulate proliferation, survival, and differentiation of dopaminergic neural precursors (Morrison et al., 2000; Studer et al., 2000).

In conclusion, we show that intrastriatal CB transplants induce long-term cellular and functional recovery of hemiparkinsonian rats because of trophic restoration of the intrinsic nigrostriatal pathway. CB cells in adult rodents express high levels of GDNF but, although highly dopaminergic, are protected from dopamine-mediated oxidative damage because of the absence of the high-affinity dopamine transporter. These results should encourage studies designed to test the neuroprotective and restorative effects of $\mathrm{CB}$ autotransplants in $\mathrm{PD}$ patients.

\section{References}

Akerud P, Canals JM, Snyder EY, Arenas E (2001) Neuroprotection through delivery of glial cell line-derived neurotrophic factor by neural stem cells in a mouse model of Parkinson's disease. J Neurosci 21:8108-8118.

Ambrosio S, Mintenig GM, Palacios-Araus L, Mahy N, Palés J, Gual A (1990) Lack of effect of MPTP on a peripheral dopaminergic structure: the carotid body. In: Arterial chemoreception (Eyzaguirre C, Fidone SJ, Fitzgerald RS, Lahiri S, McDonald DM, eds), pp 186-191. New York: Springer.

Björklund A, Lindvall O, Isacson O, Brundin P, Wictorin K, Strecker RE, Clarke DJ, Dunnett SB (1987) Mechanisms of action of intracerebral neural implants: studies on nigral and striatal grafts to the lesioned striatum. Trends Neurosci 10:509-516.

Bohn MC, Cupit L, Marciano F, Gash DM (1987) Adrenal medulla grafts enhance recovery of striatal dopaminergic fibers. Science 237:913-916.

Burns RS, Chiueh CC, Markey SP, Ebert MH, Jacobowitz DM, Kopin IJ (1983) A primate model of parkinsonism: selective destruction of dopaminergic neurons in the pars compacta of the substantia nigra by $N$-methyl-4-phenyl-1,2,3,6-tetrahydropyridine. Proc Natl Acad Sci USA $80: 4546-4550$

Choi-Lundberg DL, Lin Q, Chang YN, Chiang YL, Hay CM, Mohajeri H, Davidson BL, Bohn MC (1997) Dopaminergic neurons protected from degeneration by GDNF gene therapy. Science 275:838-841.

Conway KA, Rochet JC, Bieganski RM, Lansbury Jr PT (2001) Kinetic stabilization of the alpha-synuclein protofibril by a dopamine-alphasynuclein adduct. Science 294:1346-1349.

Deacon T, Schumacher J, Dinsmore J, Thomas C, Palmer P, Kott S, Edge A, Penney D, Kassissieh S, Dempsey P, Isacson O (1997) Histological evidence of fetal pig neural cell survival after transplantation into a patient with Parkinson's disease. Nat Med 3:350-353.

Dunnett SB, Bjorklund A (1999) Prospects for new restorative and neuroprotective treatments in Parkinson's disease. Nature 399:A32-A39.

Echevarría M, Ramírez-Lorca R, Hernández CS, Gutierrez A, Méndez-Ferrer S, González E, Toledo-Aral JJ, Ilundain AA, Whittembury G (2001) Identification of a new water channel (Rp-MIP) in the malpighian tubules of the insect Rhodnius prolixus. Pflügers Arch 442:27-34.

Erickson JT, Brosenitsch TA, Katz DM (2001) Brain-derived neurotrophic factor and glial cell line-derived neurotrophic factor are required simultaneously for survival of dopaminergic primary sensory neurons in vivo. J Neurosci 21:581-589.

Espejo EF, Montoro RJ, Armengol JA, López-Barneo J (1998) Cellular and functional recovery of parkinsonian rats after intrastriatal transplantation of carotid-body cell aggregates. Neuron 20:197-206.
Fariñas I, Jones KR, Backus C, Wang X-Y, Reichardt LF (1994) Severe sensory and sympathetic deficits in mice lacking neurotrophin-3. Nature 369:658-661.

Freed CR, Breeze RE, Rosenberg NL, Schneck SA, Kriek E, Qi JX, Lone T, Zhang YB, Snyder JA, Wells TH, Ramig LO, Thompson L, Mazziotta JC, Huang SC, Grafton ST, Brooks D, Sawle G, Schroter G, Ansari AA(1992) Survival of implanted fetal dopamine cells and neurologic improvement 12 and 46 months after transplantation for Parkinson's disease. N Engl J Med 327:1549-1555.

Freed CR, Greene PE, Breeze RE, Tsai WY, DuMouchel W, Kao R, Dillon S, Winfield H, Culver S, Trojanowski JQ, Eidelberg D, Fahn S (2001) Transplantation of embryonic dopamine neurons for severe Parkinson's disease. N Engl J Med 344:710-719.

Gainetdinov RR, Fumagalli F, Jones SR, Caron MG (1997) Dopamine transporter is required for in vivo MPTP neurotoxicity: evidence from mice lacking the transporter. J Neurochem 69:1322-1325.

Gash DM, Zhang Z, Ovadia A, Cass WA, Yi A, Simmerman L, Russell D, Martin D, Lapchak P A, Collins F, Hoffer BJ, Gerhardt GA (1996) Functional recovery in parkinsonian monkeys treated with GDNF. Nature 380:252-255.

Hansen JT, Skai K, Greenamyre JT, Moran S (1995) Sprouting of dopaminergic fibers from spared mesencephalic dopamine neurons in the unilateral partial lesioned rat. Brain Res 670:197-204.

Honda Y (1992) Respiratory and circulatory activities in carotid bodyresected humans. J Appl Physiol 73:1-8.

Jenner P (1998) Oxidative mechanisms in nigral cell death in Parkinson's disease. Mov Disord 13 [Suppl 1]:24-34.

Kordower JH, Freeman TB, Snow BJ, Vingerhoets FJG, Mufson EJ, Sanberg PR, Hauser RA, Smith DA, Nauert GM, Perl DP, Olanow CW (1995) Neuropathological evidence of graft survival and striatal reinnervation after the transplantation of fetal mesencephalic tissue in a patient with Parkinson's disease. N Engl J Med 332:1118-1124.

Kordower JH, Emborg ME, Bloch J, Ma SY, Chu Y, Leventhal L, McBride J, Chen EY, Palfi S, Roitberg BZ, Brown WD, Holden JE, Pyzalski R, Taylor MD, Carvey P, Ling Z, Trono D, Hantraye P, Deglon N, Aebischer P (2000) Neurodegeneration prevented by lentiviral vector delivery of GDNF in primate models of Parkinson's disease. Science 290:767-773.

Lang AE, Lozano AM (1998a) Parkinson's disease, Pt 1. N Engl J Med 339:1044-1053.

Lang AE, Lozano AM (1998b) Parkinson's disease, Pt 2. N Engl J Med 339:1130-1143.

Lin LF, Doherty DH, Lile JD, Bektesh S, Collins F (1993) GDNF: a glial cell line-derived neurotrophic factor for midbrain dopaminergic neurons. Science 260:1130-1132.

López-Barneo J, Pardal R, Ortega-Sáenz P (2001) Cellular mechanism of oxygen sensing. Annu Rev Physiol 63:259-287.

Luquin MR, Montoro RJ, Guillén J, Saldise L, Insausti R, Del Río J, LópezBarneo J (1999) Recovery of chronic parkinsonian monkeys by autotransplants of carotid body cell aggregates into putamen. Neuron 22:743-750.

Martres M-P, Demeneix B, Hanoun N, Hamon M, Giros B (1998) Up- and down-expression of the dopamine transporter by plasmid DNA transfer in the rat brain. Eur J Neurosci 10:3607-3616.

McGregor KH, Gil J, Lahiri S (1984) A morphometric study of the carotid body in chronically hypoxic rats. J Appl Physiol 57:1430-1438.

Mínguez A, López-Barneo J, Arjona V, Montoro RJ, Escamilla F, Ortega A, Toledo-Aral JJ, Pardal R, Méndez-Ferrer S, Martín JM, Pérez M, García T (2001) Transplantation of carotid body cell aggregates in patients with Parkinson's disease: a pilot study. Parkinsonism Relat Disord 7:S82.

Moreau E, Vilar J, Lelievre-Pegorier M, Merlet-Benichou C, Gilbert T (1998) Regulation of c-ret expression by retinoic acid in rat metanephros: implication in nephron mass control. Am J Physiol 275:F938-F945.

Morrison SJ, Csete M, Groves AK, Melega W, Wold B, Anderson DJ (2000) Culture in reduced levels of oxygen promotes clonogenic sympathoadrenal differentiation by isolated neural crest stem cells. J Neurosci 20:7370-7376.

Nieto MA, Patel K, Wilkinson DG (1996) In situ hybridization analysis of chick embryos in whole mount and tissue sections. Methods Cell Biol 51:219-235.

Nosrat CA, Tomac A, Lindqvist E, Lindskog S, Humpel C, Stromberg I, Ebendal T, Hoffer BJ, Olson L (1996) Cellular expression of GDNF mRNA suggests multiple functions inside and outside the nervous system. Cell Tissue Res 286:191-207. 
Offen D, Hochman A, Gorodin S, Ziv I, Shirvan A, Barzilai A, Melamed E (1999) Oxidative stress and neuroprotection in Parkinson's disease: implications from studies on dopamine-induced apoptosis. Adv Neurol 80:265-269.

Pardal R, Ludewig U, García-Hirschfeld J, López-Barneo J (2000) Secretory responses of intact glomus cells in thin slices of rat carotid body to hypoxia and tetraethylammonium. Proc Natl Acad Sci USA 97:2361-2366.

Rosenblad C, Martínez-Serrano A, Bjorklund A (1998) Intrastriatal glial cell line-derived neurotrophic factor promotes sprouting of spared nigrostriatal dopaminergic afferents and induces recovery of function in a rat model of Parkinson's disease. Neuroscience 82:129-137.

Rosenthal A (1998) Auto transplants for Parkinson's disease? Neuron 20:169-172.

Rosenthal A (1999) The GDNF protein family: gene ablation studies reveal what they really do and how. Neuron 22:201-207.

Sánchez MP, Silos-Santiago I, Frisén J, He B, Lira SA, Barbacid M (1996) Renal agenesis and the absence of enteric neurons in mice lacking GDNF. Nature 382:70-73.

Schwarting RKW, Huston JP (1996) Unilateral 6-hydroxydopamine lesions of mesostriatal dopamine neurons and their physiological sequelae. Prog Neurobiol 49:215-266.
Sladek Jr JR, Gash DM (1988) Nerve cell grafting in Parkinson's disease. J Neurosurg 68:337-351.

Song DD, Haber SN (2000) Striatal responses to partial dopaminergic lesion: evidence for compensatory sprouting. J Neurosci 20:5102-5114.

Spina MB, Cohen G (1989) Dopamine turnover and glutathione oxidation: implications for Parkinson disease. Proc Natl Acad Sci USA 86:1398-1400.

Studer L, Csete M, Lee SH, Kabbani N, Walikonis J, Wold B, McKay R (2000) Enhanced proliferation, survival, and dopaminergic differentiation of CNS precursors in lowered oxygen. J Neurosci 20:7377-7383.

Toledo-Aral JJ, Méndez-Ferrer S, Pardal R, López-Barneo J (2002) Dopaminergic cells of the carotid body: physiological significance and possible therapeutic applications in Parkinson's disease. Brain Res Bull 57:847-853.

Tomac A, Lindqvist E, Lin LFH, Ogren SO, Young D, Hoffer BJ, Olson L (1995a) Protection and repair of the nigrostriatal dopaminergic system by GDNF in vivo. Nature 373:335-339.

Tomac A, Widenfalk J, Lin L-FH, Kohno T, Ebendal T, Hoffer BJ, Olson L (1995b) Retrograde axonal transport of glial cell line-derived neurotrophic factor in the adult nigrostriatal system suggests a trophic role in the adult. Proc Natl Acad Sci USA 92:8274-8278. 